\title{
EFFECT OF DIETARY LEMONGRASS (Cymbopogon citratus) AND ROSELLE (Hibiscus sabdariffa) TO SAIDI EWES ON: (A) MILK PRODUCTION, RUMEN FERMENTATION AND LAMB'S PERFORMANCE
}

\author{
M.A.M. Abdullah ${ }^{1}$, M.W.H. Daghash ${ }^{1}$, M.G.M. Bakheet ${ }^{1}$ and Asmaa H.M.Moneeb ${ }^{2}$ \\ 1- Department of Animal Production, Faculty of Agriculture, Assiut University, Assiut, 71526, Egypt, 2- \\ Department of Dairy Science, Faculty of Agriculture, Assiut Uni., Assiut, 71526, Egypt
}

Received: $10 / 9 / 2019$

Accepted: 17/10/2019

\section{SUMMARY}

The experiment was carried out to study the influence of Lemongrass and Roselle supplementation in the diet of Saidi ewes. Twenty-eight ewes in the last month of pregnancy with an average body weight of $45 \pm 2 \mathrm{~kg}$ were assigned to 4 treatment groups ( 7 ewes in each group) for 75 days (15 before parturition and 60 days after parturition) using completely randomized block design. The treatments included: (1) control group (CON): received a ration consisted of concentrate mixture and wheat straw as 60:40\% on dry matter (DM) bases; (2) $L G$ treatment group: the ewes were fed the control ration plus $4 \mathrm{~g}$ dried Lemongrass $/ \mathrm{kg}$ of concentrate mixture; (3) RO treatment group: the ewes were fed the control ration plus $4 \mathrm{~g}$ dried Roselle/kg of concentrate mixture; and (4) LGRO treatment group: the ewes were fed the control ration plus $2 g$ dried Lemongrass and $2 g$ dried Roselle $/ \mathrm{kg}$ of concentrate mixture. Milk yield was recorded biweekly and milk samples were taken to analyze its chemical composition. Rumen liquor samples were collected to measure the $\mathrm{pH}$, total volatile fatty acids (VFA's) concentration and protozoal count. Lambs were weighed at birth and then once a week during four weeks of the experiment period and the daily weight gain (DWG) was calculated.

Results revealed that milk efficiency as fat corrected milk (FCM) and milk yield/DM intake were not significantly affected by Lemongrass or Roselle supplementation. Milk yield tended to increase $(P>0.05)$ in treated ewes. Milk fat increased $(P<0.05)$ in milk of ewes fed lemongrass diet compared to those fed the other diets. In rumen samples, the protozoal count was significantly higher due to Lemongrass and Roselle supplementation together compared to the control and LGRO diets. Also, there was a highly significant increase in total VFA's concentration in LGRO and RO compared to the CON group. Also, there was a signifncant $(P<0.05)$ increase in milk total solids, solids not fat, protein and lactose in ewes fed lemongrass and Roselle diets compared with those fed control diet. In addition, milk density percent was higher $(P<0.05)$ in milk of treated ewes compared to untreated ones, whereas minerals content did not differ among groups. Both body weight of lambs and daily gain of treated groups were not significantly affected by the experimental additives.

Finally, the findings of this study revealed that the addition of lemongrass and Roselle herbs improved milk composition and rumen fermentation patterns without any harmful effect on animal performance.

Keywords: Lemongrass, Roselle, Lactating ewes, Milk composition, Rumen fermentation

\section{INTRODUCTION}

Herbs and their extracts have been evaluated for their ability to alter ruminal fermentation and improve nutrient utilization in ruminants (Korošec et al., 2009). Phenolic compounds are one of the most important phytochemicals in plant extracts. The main effect is to inhibit the oxidative reaction caused by oxidative stress and mitigate its consequences (Shahidi, 2006).

Lemongrass is a herb of interest, and it is widely used in human food in tropical countries, especially in Southeast Asia. The principal constituent of lemongrass extract is citral which is the essential oil for vitamin A synthesis (Kholif et al., 2017). Lemongrass herb has been reported to have antibacterial, antioxidant and anti-hyper ammoniaproducing ruminal bacterial activities (Wanapat et al., 2008).
Roselle is a species of Hibiscus native to the old world tropics (Idris et al., 2016). The extract of Roselle was reported as an antibacterial, antifungal, diuretic, uricosuric, and mild laxative substance (DaCosta-Rocha et al., 2014). In addition, the polyphenols components of Hibiscus sabdariffa extract exhibit anti-inflammatory potency (KAO et al., 2009), hypoglycemic, hypolipidemic, antioxidant effects, and induce tumor cell apoptosis (Chiu et al., 2015). Few studies have been conducted to study the effect of Roselle and Lemongrass herbs inclusion on milk composition, rumen fermentation and lambs growth rate. The objective of this experiment was to study the effect of dried roselle and lemongrass powder supplementation on dry matter intake , lamb's growth performance, rumen ecology and milk production of Saidi ewes. 


\section{MATERIALS AND METHODS}

Experimental location, duration, and animals:

The experiment was carried out at the Research Farm of Animal Production Department, Faculty of Agriculture, Assuit University, Assuit, Egypt. Twenty-eight pregnant Saidi ewes (at the $3^{\text {rd }}$ or $4^{\text {th }}$ lactating seasons and weighing an average $45.2 \pm 2 \mathrm{~kg}$ ) were used. The experiment lasted for 75 days starting from 15 days before parturition and 60 days after parturition.

\section{Diet and experimental design:}

Dry Lemongrass (Cymbopogon citratus) and Roselle (Hibiscus sabdariffa) were obtained from a local supplier in Assiut, Egypt. Ewes were divided into four groups (seven each group) and allocated randomly to one of four dietary treatments using completely randomized block design. The dietary treatment groups were as follows; (1) control group $(\mathrm{CON})$ : received a ration consisted of concentrate mixture and wheat straw as 60:40\%, as a dry matter
(DM) basis; (2) LG treatment group: the ewes were fed the control ration plus $4 \mathrm{~g}$ dried Lemongrass $/ \mathrm{kg}$ of concentrate mixture; (3) RO treatment group: the ewes were fed the control ration plus $4 \mathrm{~g}$ dried Roselle/kg of concentrate mixture; and (4) LGRO treatment group: the ewes were fed the control ration plus $2 \mathrm{~g}$ dried Lemongrass and $2 \mathrm{~g}$ dried Roselle $/ \mathrm{kg}$ of concentrate mixture. Tested feed additives were homogeneously mixed with the concentrate mixture. The offered feeds were assessed to cover the maintenance and production requirements for each animal (NRC, 1985). The concentrate mixture was offered for each animal individually once daily at $9.00 \mathrm{am}$, while wheat straw was offered at $12.00 \mathrm{hr}$. Fresh water was provided ad libitum.

Samples of feed ingredients were chemically analyzed for dry matter, ash, crude protein and ether extract according to methods of (AOAC, 2012). The neutral detergent fiber (NDF) and acid detergent fiber (ADF) were indentified according to (Van Soest et al., 2010). The chemical composition of the ingredients is shown in Table 1.

Table 1. The ingredients and chemical composition of the experimental diets

\begin{tabular}{|c|c|}
\hline Item & $(\mathrm{g} / \mathrm{kg}$ control ration $) *$ \\
\hline Wheat Straw & 400 \\
\hline Maize Grain & 300 \\
\hline Soybean Meal & 90 \\
\hline Sunflower Meal & 72 \\
\hline Wheat Bran & 120 \\
\hline Limestone & 12 \\
\hline Sodium chloride & 3 \\
\hline Trace mineral and vitamin premix ${ }^{£}$ & 3 \\
\hline Total & 1000.00 \\
\hline \multicolumn{2}{|l|}{ Chemical composition (g/kg DM basis) } \\
\hline $\mathrm{OM}$ & 822.69 \\
\hline $\mathrm{CP}$ & 116.95 \\
\hline $\mathrm{EE}$ & 28.46 \\
\hline NDF & 424.23 \\
\hline $\mathrm{ADF}$ & 235.71 \\
\hline
\end{tabular}

* CON: Control ration consisted of concentrate mixture and wheat straw (60:40\% as DM basis).

${ }^{\mathfrak{E}}$ The premix comprised (per kg) 20,000,000 IU vitamin A, 200,000 IU vitamin D3, 10,000 mg vitamin E, 10,000 mg Fe, $2500 \mathrm{mg} \mathrm{Cu}, 20,000 \mathrm{mg} \mathrm{Mn}, 100 \mathrm{mg} \mathrm{Mo,} 100 \mathrm{mg} \mathrm{Co}, 800 \mathrm{mg} \mathrm{I}, 20,000 \mathrm{mg} \mathrm{Zn}$ and $100 \mathrm{mg}$ Se.

\section{Voluntary feed intake and lambs' growth} performance:

Feed intake (g/ewe/day) was daily recorded by weighing the offered diets and subtracting the refusal obtained the following day during the experimental period. Ewes were weighed at the beginning of the experiment and over two weeks to adjust the feed requirements. Lambs were weighed at birth and then once a week during four weeks of the experimental period and daily weight gain (DWG) was calculated.

\section{Sampling and analysis of rumen liquor:}

Rumen liquor samples were collected from 4 animals in each group by using a stomach tube at the end of the trial Sampling was performed 3-4 hrs after offering the dietary concentrate ration. Rumen liquor samples were divided into two parts, the first part was filtrated through one layer of cheese-cloth, and was used to measure the protozoal count, while the second part was filtrated through four layers of cheese-cloth and the $\mathrm{pH}$ of filtrate portion was immediately measured using a $\mathrm{pH}$ meter. Few drops of a saturated solution of mercuric chloride were added to the filtrates to stop the microbial activity, and then the samples were stored at $-20^{\circ} \mathrm{C}$ to determine total volatile fatty acids (total VFA's) utilizing the procedures of (Warner, 1964). 


\section{Milk yield and its composition:}

After 15 days of lambing and by using lambs suckling technique, the daily milk yield was measured as reported by (Ashmawy, 1980). Then the milk was mixed thoroughly to get a homogeneous sample per animal and the daily milk yield was recorded. For the analysis of milk composition, a sample of $100 \mathrm{ml}$ per animal per day was collected individually from all animals and every two weeks during the experiment lactating period (60 days). Milk samples were analysed for total solids, fat, protein, lactose, density and minerals using an ultrasonic milk analyzer (Lactoscan MCCWS, Milkotronic Ltd, Bulgaria).

\section{Experimental design and statistical analysis :}

Data of dry matter intake, milk yield and chemical composition of milk samples from ewes were subjected to repeated measurement analysis of variance (ANOVA) with sampling period as the repeated factor, experimental diets as fixed factor and ewes as a random factor.

The model used was: Yijk $=\mu+\alpha i+$ eij $+\delta i j k$, where: $Y_{i j k}=$ The $i j k^{\text {th }}$ observation, $\mu=$ The general mean, $\alpha \mathrm{i}=$ The effect of the $\mathrm{i}^{\text {th }}$ treatment $(i=\mathrm{C}, \mathrm{LG}$, RO, LGRO ), eij $=$ The experimental error and $\delta \mathrm{ijk}=$ is the sampling error.

The data of the rumen parameters, the body weight and changes of body weight of ewes and the daily weight gain of lambs were evaluated using the General Linear Models (GLM) procedure for analysis of variance. The model used was: Yijk $=\mu+\alpha i+$ eij, where Yijk $=$ The $\mathrm{ijk}^{\text {th }}$ observation, $\mu=$ The overall mean, $\alpha i=$ The effect of the $i^{\text {th }}$ treatment $(i=C, L G$, RO, LGRO) and eij $=$ The experimental error.

Duncan's multiple range tests were used to detect the differences among the treatments using the SPSS statistical package 22 (SPSS Institute, Chigaco, IL, USA). The data are presented as means \pm SE. Probability values less than $0.05(\mathrm{P}<0.05)$ was considered significant.

\section{RESULTS AND DISCUSSION}

\section{Dry matter intake and milk yield:}

Dry matter intake $(\mathrm{g} / \mathrm{d})$ was not significantly affected by dietary treatment of either lemingrass or roseolle (Table 2). Similary, Kholif et al. (2017) and (Wanapat et al., 2008) found no significant effect of feeding rosemary and lemongrass on DM intake by Damascus goats and cows, respectively.

The average daily milk yield, fat corrected milk and milk yield/DMI were not significantly affected by dietary lemongrass and roselle (Table 2). Milk yield recorded in the present trial is comparable with previous work in Egypt for ewes (654.3 g/day) rearing single lambs) (Abd Allah et al., 2011). However, Kholif et al. (2017) found that an increase of milk yield in lactating Damascus goats fed rosemary and lemongrass diets. In addition, dietary lemongrass residue as feed for cows increased 23\% of the milk production as reported by (Manurung et al., 2015). This difference in the results could be attributed to the difference of the animal type. Enhanced ruminal fermentation with feeding lemongrass is likely the main reason for higher milk production (Kholif et al., 2017). In addition, elevating milk yield reported in the present study may have been influenced by the phenolic compounds found in lemongrass. Ruminal fermentation processes could be enhanced by phenolic compounds which create a strictly anaerobic environment in the rumen(Salem et al., 2014b).

Table 2. Effect of treatments on dry matter intake and milk performance of Saidi ewes

\begin{tabular}{lllll}
\hline \multicolumn{1}{c}{ Item } & \multicolumn{4}{c}{ Treatment* } \\
\cline { 2 - 5 } Live body weight, $\mathbf{~ k g}$ & CON & LG & RO & LGRO \\
Dry matter intake, g/d & $45.14 \pm 3.81$ & $44.87 \pm 2.70$ & $45.28 \pm 2.81$ & $45.14 \pm 2.83$ \\
Milk yield, g/d & 1205 & 1192 & 1232 & 1253 \\
Fat corrected milk, 4\% & $648.06 \pm 6.41$ & $660 \pm 8.66$ & $670.60 \pm 5.29$ & $682.03 \pm 5.79$ \\
Milk yield/DMI & $804.95 \pm 22.16$ & $741.37 \pm 20.74$ & $759.79 \pm 19.55$ & $793.20 \pm 17.32$ \\
\hline${ }^{*}$ CON: Control ration consisted of concentrate mixture and wheat straw as 60:40 \%, as a dry matter (DM) basis; LG \\
treatment group: the ewes fed control ration plus 4g dried Lemongrass/kg of concentrate mixture; RO treatment group: the \\
ewes fed control ration plus 4g dried Roselle/kg of concentrate mixture; and LGRO treatment group: the ewes fed control \\
ration plus 2g dried Lemongrass and 2 g dried Roselle /kg of concentrate mixture.
\end{tabular}

\section{Rumen Liquor Parameters:}

The effect of the experimental additives on rumen parameters are shown in Table 3. Ruminal $\mathrm{pH}$ values were not significantly affected by the experimental additives. The $\mathrm{pH}$ was within the range considered optimal for microbial digestion of fiber and protein (Ryle and Ørskov, 2011). This result agrees with Kholif et al. (2017) who reported that the rumen $\mathrm{pH}$ values in lactating Barki goats were not changed between control and goats treated with lemongrass.
There was a higher significant $(\mathrm{P}<0.05)$ increase in concentration of total VFA's in the rumen fluid of ewes fed RO and LGRO diets compared to those received LG or CON diets (Table 3). However, feeding ewes diets with LG and RO together decreased $(\mathrm{P}<0.05)$ total protozoal count compared to feeding LG or RO separately. Similar results were reported by Kholif et al. (2017) and Nanon et al. (2014) who found that dietary LG had effect on the concentration of rumen total VFA's. The higher concentration of total VFA's for RO and LGRO 
groups cleared that adding these herbs to the ruminant diet could change the microbial population and rumen fermentation (Nikaido, 1994). These results indicate that the herb additives stimulate rumen protozoal activity and enhance digestibility which is in accordance with those noted by (Busquet et al., 2005; Castillejos et al., 2010 and Kongmun et al., 2010). Volatile fatty acids are the end products of rumen microbial fermentation and represent the main supply of metabolizable energy for ruminants (Van Soest, 1994).

Table 3 Effect of treatments on rumen parameters of Saidi ewes

\begin{tabular}{lllll}
\hline Item & \multicolumn{3}{c}{ Treatments* } \\
\cline { 2 - 5 } & CON & LG & RO & LGRO \\
\hline pH value & $6.00 \pm 0.11$ & $5.90 \pm 0.07$ & $6.08 \pm 0.09$ & $6.05 \pm 0.05$ \\
Total VFA's, m-equiv/ 100 $\mathbf{~ m L}$ & $7.00^{\mathrm{c}} \pm 0.58$ & $7.75^{\mathrm{bc}} \pm 0.25$ & $9.75^{\mathrm{a}} \pm 0.75$ & $9.25^{\mathrm{ab}} \pm 0.75$ \\
Protozoa count, $\mathbf{1 0}^{\mathbf{5}}$ & $9.38^{\mathrm{b}} \pm 0.22$ & $20.10^{\mathrm{a}} \pm 0.37$ & $13.05^{\mathrm{a}} \pm 0.66$ & $9.29^{\mathrm{b}} \pm 0.83$ \\
\hline
\end{tabular}

Values are mean of 7 samples \pm SE. Samples were taken 3 hrs. after feeding .

$a, b$, means at the same row with different superscript are significantly different $(\mathrm{P}<0.05)$.

${ }^{*} \mathrm{CON}$ : Control ration consisted of concentrate mixture and wheat straw as 60:40\%, as a dry matter (DM) basis; LG treatment group: the ewes fed control ration plus $4 \mathrm{~g}$ dried Lemongrass $/ \mathrm{kg}$ of concentrate mixture; RO treatment group: the ewes fed control ration plus $4 \mathrm{~g}$ dried Roselle/ $\mathrm{kg}$ of concentrate mixture; and LGRO treatment group: the ewes fed control ration plus $2 \mathrm{~g}$ dried Lemongrass and $2 \mathrm{~g}$ dried Roselle $/ \mathrm{kg}$ of concentrate mixture.

The protozoal count was significantly high in the rumen liquor of ewes fed LG (Fig. 1b) and RO (Fig. 1c) diets compared to those fed LGRO and CON diet (Fig. 1 a and Fig. 1d, respectively). These results agree with those reported by Khattab et al. (2017) who found that dietary Lemongrass significantly increased protozoa count in the rumen

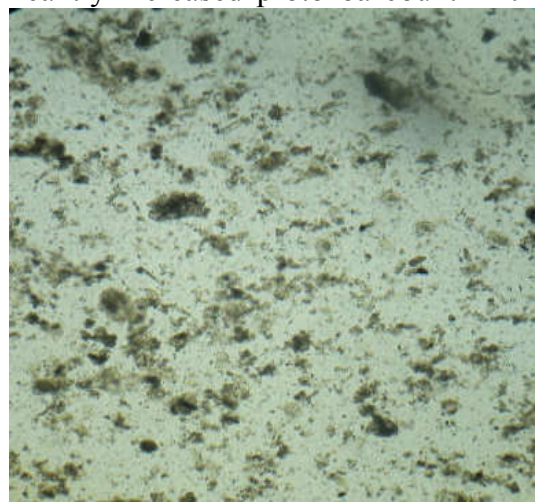

Fig. 1a : CON group

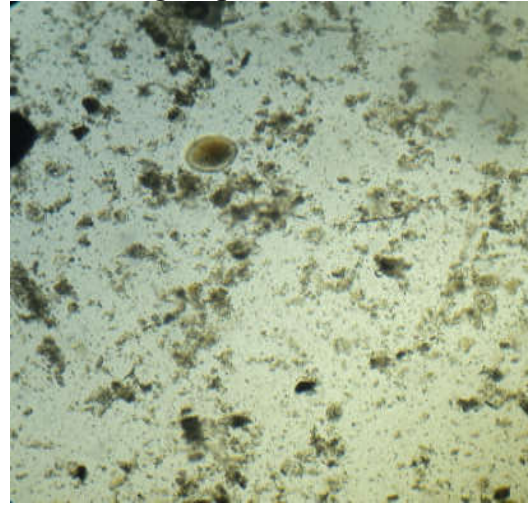

Fig. 1c: RO group (slight increase) of lactating Baladi goats. In this field, the presence of secondary metabolites in the herbs may have optimized the availability and activity of the rumen microflora and other ruminal function resulting in improved nutrient digestion by goats (Wanapat et al., 2008).

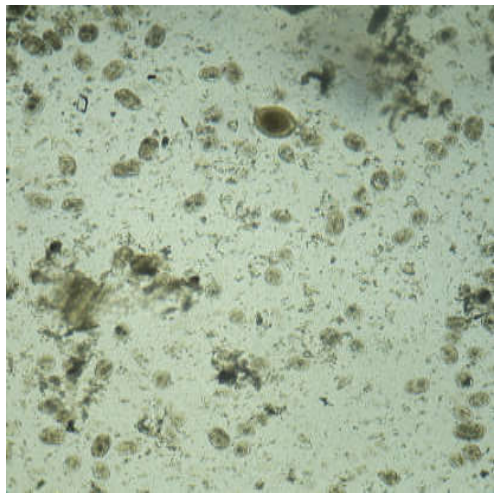

Fig. 1b: LG group (Marked increase)

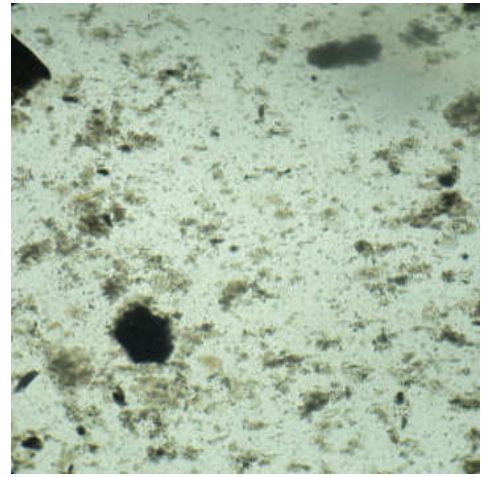

Fig. 1d: LGRO group(unmarked increase)

Figure 1 Effect of dietary lemongrass and Roselle on protozoal count of Saidi ewes

\section{Milk composition:}

The effect of feeding lemongrass and Roselle on milk composition of Saidi ewes is presented in Table (4). Data showed that milk concentrations of fat, total solids, solids not fat, protein and lactose were increased $(\mathrm{P}<0.05)$ with lemongrass and Roselle supplementation. In addition, density percent was higher $(\mathrm{P}<0.05)$ in treated ewes compared to 
untreated ewes, whereas mineral content did not differ among groups. Kholif et al .(2017) found in lactating Damascus goats that feeding rosemary and lemongrass diets have increased milk constituents compared to the control diet. The increase of milk fat content with feeding lemongrass in the present study (Table 4) may be due to increased acetate production in the rumen as reported by Kholif et al. (2017). They added that milk fat content and milk fatty acid composition depend mainly on dietary feed, animal and environmental factors, with the major effect being feed. Moreover, ruminal acetate/propionate ratio plays a fundamental role in the synthesis of milk fat. Inclusion of lemongrass and Roselle produced milk with higher lactose content (Table 4). Propionate is the precursor for gluconeogenesis and lactose synthesis, and increasing glucogenic precursors has a favorable effect on milk lactose content. In addition, a high milk constituents (fat, SNF, TS, protein and lactose contents) reported in the present study, may have been influenced by the phenolic compounds found in Lemongrass and Roselle which could improve ruminal fermentation processes by creating a strictly anaerobic environment (Bodas et al., 2012; Salem et al., 2014a).

Table 4. Effect of treatments on milk composition of Saidi ewes

\begin{tabular}{lllll}
\hline Item & \multicolumn{4}{c}{ Treatments* } \\
\cline { 2 - 5 } & CON & LG & RO & LGRO \\
\hline Fat, \% & $4.85^{\mathrm{b}} \pm 0.22$ & $5.61^{\mathrm{a}} \pm 0.19$ & $4.89^{\mathrm{b}} \pm 0.19$ & $5.09^{\mathrm{ab}} \pm 0.19$ \\
SNF, \% & $8.36^{\mathrm{b}} \pm 0.52$ & $9.51^{\mathrm{ab}} \pm 0.52$ & $9.75^{\mathrm{a}} \pm 0.52$ & $10.05^{\mathrm{a}} \pm 0.52$ \\
Total solids, \% & $13.31^{\mathrm{b}} \pm 0.72$ & $15.12^{\mathrm{a}} \pm 0.61$ & $14.64^{\mathrm{ab}} \pm 0.61$ & $15.14^{\mathrm{a}} \pm 0.61$ \\
Protein, \% & $3.02^{\mathrm{b}} \pm 0.11$ & $3.51^{\mathrm{a}} \pm 0.11$ & $3.49^{\mathrm{a}} \pm 0.11$ & $3.54^{\mathrm{a}} \pm 0.11$ \\
Lactose, \% & $4.56^{\mathrm{b}} \pm 0.16$ & $5.27^{\mathrm{a}} \pm 0.19$ & $5.23^{\mathrm{a}} \pm 0.16$ & $5.33^{\mathrm{a}} \pm 0.16$ \\
Density, \% & $29.67^{\mathrm{b}} \pm 0.98$ & $33.83^{\mathrm{a}} \pm 0.98$ & $34.23^{\mathrm{a}} \pm 0.98$ & $34.26^{\mathrm{a}} \pm 0.98$ \\
\hline Minerals, \% & $0.85 \pm 0.04$ & $0.83 \pm 0.05$ & $0.76 \pm 0.04$ & $0.81 \pm 0.04$ \\
\hline
\end{tabular}

Each value represents an average of twenty-one samples.

$\mathrm{a}, \mathrm{b}$ means at the same row with different superscript are significantly $(\mathrm{P}<0.05)$ different.

*CON: Control ration consisted of concentrate mixture and wheat straw as 60:40\%, as a dry matter (DM) basis; LG treatment group: the ewes fed control ration plus $4 \mathrm{~g}$ dried Lemongrass $/ \mathrm{kg}$ of concentrate mixture; RO treatment group: the ewes fed control ration plus $4 \mathrm{~g}$ dried Roselle/kg of concentrate mixture; and LGRO treatment group: the ewes fed control ration plus $2 \mathrm{~g}$ dried Lemongrass and $2 \mathrm{~g}$ dried Roselle $/ \mathrm{kg}$ of concentrate mixture.

\section{Lamb's growth performance:}

The effects of the experimental additives on average body weight and daily gain of lambs are shown in (Table 5). Both body weight and daily gain of treated lambs were not significantly affected by the experimental additives. These results are in agreement with those reported by (Beshir and Babikers, 2009) who found that dietary treatments with RO levels (10 and 20\%) in the diets of male lambs of Sudan desert sheep ecotype Kabashi had no significant effect on average daily gain and final body weight. However, (Sariözkan et al., 2016) observed that the quail diet supplemented with 3\% LG leaf meal showed a significantly lower final body weight compared to the control $(\mathrm{P}<0.05)$. This finding was similar to those ofTiwari et al., (2018) who reported that reduced body weight in broilers fed with $2 \%$ LG leaf supplemented diet. However, this result was contrary to those of (Mmereole, 2010; Mukhtar et al., 2012) who reported that supplementation of LG leaf meal or oil resulted in significantly higher body weight in broilers.

Table 5 . Effect treatments on lamb's growth performance

\begin{tabular}{|c|c|c|c|c|}
\hline \multirow[t]{2}{*}{ Period } & \multicolumn{4}{|c|}{ Treatment* } \\
\hline & $\operatorname{CON}(n=7)$ & LG (n=7) & RO $(n=8)$ & LGRO (n=9) \\
\hline $1^{\text {st }} \mathbf{W K}$ & $3.51 \pm 0.19$ & $3.43 \pm 0.41$ & $3.42 \pm 0.41$ & $3.00 \pm 0.30$ \\
\hline $2^{\text {nd }} W K$ & $6.61 \pm 0.56$ & $6.44 \pm 0.62$ & $6.12 \pm 0.62$ & $6.15 \pm 0.58$ \\
\hline $3^{\text {rd }}$ WK & $7.67 \pm 0.58$ & $7.87 \pm 0.83$ & $6.95 \pm 0.83$ & $7.08 \pm 0.71$ \\
\hline $4^{\text {th }}$ WK & $9.37 \pm 0.81$ & $9.65 \pm 1.15$ & $8.36 \pm 1.15$ & $8.55 \pm 0.98$ \\
\hline Daily weight gain (g/day) & $180 \pm 0.30$ & $200 \pm 0.40$ & $140 \pm 0.40$ & $160 \pm 0.45$ \\
\hline
\end{tabular}

*CON: Control ration consisted of concentrate mixture and wheat straw as 60:40\%, as a dry matter (DM) basis; LG treatment group: the ewes fed control ration plus $4 \mathrm{~g}$ dried Lemongrass $/ \mathrm{kg}$ of concentrate mixture; RO treatment group: the ewes fed control ration plus $4 \mathrm{~g}$ dried Roselle/kg of concentrate mixture; and LGRO treatment group: the ewes fed control ration plus $2 \mathrm{~g}$ dried Lemongrass and $2 \mathrm{~g}$ dried Roselle $/ \mathrm{kg}$ of concentrate mixture.

\section{CONCLUSION}

Finally, from the present findings, it could be concluded that the addition of lemongrass and Roselle herbs can be used in dairy ewes without any harmful effect on animal performance. These kinds of herbs and at this level $(4 \mathrm{~g} / \mathrm{kg}$ of concentrate mixture), succeed to improve milk composition and rumen fermentation in treatment ewes but this effect did not pass to their lambs. 


\section{REFERENCES}

Abd Allah, M., S. F. Abass, and F. M. Allam, 2011. Factors affecting the milk yield and composition of Rahmani and Chios sheep. Int. J. Livest. Prod. 2:024-030.

AOAC., 2012. Official methods of analysis, Association of Official Analytical Chemists, Gaithersburg, USA. 19th ed.

Ashmawy, G. M., 1980. Comparison of three techniques for the estimation of the milk production of small ruminants. Egypt. J. Anim. Prod. 20:11-16.

Beshir, A. A., and A. Babikers, 2009. Performance of sudanese desert lambs fed graded levels of roselle (Hibiscus sabdariffa) seeds instead of groundnut cake. Pak. J. Nutr. 8:1442-1445.

Bodas, R., N. Prieto, R. García-González, S. Andrés, F. J. Giráldez, and S. López, 2012. Manipulation of rumen fermentation and methane production with plant secondary metabolites. Anim. Feed Sci. Technol. 176:78-93.

Busquet, M., S. Calsamiglia, A. Ferret, and C. Kamel, 2005. Screening for effects of plant extracts and active compounds of plants on dairy cattle rumen microbial fermentation in a continuous culture system. Anim. Feed Sci. Technol. doi:10.1016/j.anifeedsci.2005.03.008.

Castillejos, L., S. Calsamiglia, and A. Ferret, 2010. Effect of Essential Oil Active Compounds on Rumen Microbial Fermentation and Nutrient Flow in In Vitro Systems. J. Dairy Sci. doi:10.3168/jds.s0022-0302(06)72341-4.

Chiu, C.-T., J.-H. Chen, F.-P. Chou, H.-H. Lin, C.-T. Chiu, J.-H. Chen, F.-P. Chou, and H.-H. Lin, 2015. Hibiscus sabdariffa Leaf Extract Inhibits Human Prostate Cancer Cell Invasion via DownRegulation of Akt/NF-kB/MMP-9 Pathway. Nutrients. 7:5065-5087. doi:10.3390/nu7075065.

Da-Costa-Rocha, I., B. Bonnlaender, H. Sievers, I. Pischel, and M. Heinrich, 2014. Hibiscus sabdariffa L. - A phytochemical and pharmacological review. Food Chem. 165:424443. doi:10.1016/j.foodchem.2014.05.002.

Idris, A., C. Kijora, A. M. Salih, H. Eltaher, and I. Bushara, 2016. Effect of supplementation, birth type and sex on lambs 'growth rate under range condition. Online J. Anim. Feed Res. 6:24-29.

KAO, E.-S., J.-D. HSU, C.-J. WANG, S.-H. YANG, S.-Y. CHENG, and H.-J. LEE, 2009. Polyphenols Extracted from Hibiscus sabdariffa L. Inhibited Lipopolysaccharide-Induced Inflammation by Improving Antioxidative Conditions and Regulating Cyclooxygenase -2 Expression. Biosci. Biotechnol. Biochem. 73:385-390. doi:10.1271/bbb.80639.

Khattab, M.S.A., H.M. El-Zaiat, A.M. A. El Tawab, O. H. Matloup, A. S. Morsy, M. M. Abdou, H. M. Ebeid, M. F. A. Attia, and S. M. A. Sallam, 2017. Impact of lemongrass and galangal as feed additives on performance of lactating Barki goats. Int. J. Dairy Sci. doi:10.3923/ijds.2017.184.189.
Kholif, A. E., O. H. Matloup, T. A. Morsy, M. M. Abdo, A. A. Abu Elella, U. Y. Anele, and K. C. Swanson. 2017. Rosemary and lemongrass herbs as phytogenic feed additives to improve efficient feed utilization, manipulate rumen fermentation and elevate milk production of Damascus goats. Livest. Sci. doi:10.1016/j.livsci.2017.08.001.

Kongmun, P., M. Wanapat, P. Pakdee, and C. Navanukraw. 2010. Effect of coconut oil and garlic powder on in vitro fermentation using gas production technique. Livest. Sci. doi:10.1016/j.livsci.2009.08.008.

Korošec, T. F., M. Voljč, J. Salobir, V. Rezar, and T. Frankič. 2009. Use of herbs and spices and their extracts in animal nutrition.

Manurung, R., R. Melinda, M. Y. Abduh, A. Widiana, I. Sugorc, and D. Suheryadi. 2015. Potential use of lemongrass (cymbopogon winterianus) residue as dairy cow feed. Pakistan J. Nutr. 14:919-923. doi:10.3923/pjn.2015.919.923.

Mmereole, F. U. C. 2010. Effects of lemmon grass (Cymbopogon citratus) leaf meal feed supplement on growth performance of broiler chicks. Int. J. Poult. Sci. 9:1107-1111.

Mukhtar, A., K. Mohamed, O. Amal, and A. Ahlam. 2012. Effect of different levels of lemon grass oil (lgo) as anatural growth promoter on the performance, carcass yields and serum chemistry of broiler chicks. Egypt. Poult. Sci. 33:1-7.

Nanon, A., W. Suksombat, K. A. Beauchemin, and W. Z. Yang. 2014. Short Communication: Assessment of lemongrass oil supplementation in a dairy diet on in vitro ruminal fermentation characteristics using the rumen simulation technique. Can. J. Anim. Sci. doi:10.4141/cjas2014-019.

Nikaido, H. 1994. Prevention of drug access to bacterial targets: Permeability barriers and active efflux. Science (80-.). doi: 10.1126/science. 8153625 .

NRC. 1985. Nutrient requirements of sheep. National Academies.

Ryle, M., and E. R. Ørskov. 2011. Energy Nutrition in Ruminants.

Salem, A. Z. M., A. E. Kholif, M. M. Y. Elghandour, S. R. Hernandez, I. A. Domínguez $\square$ Vara, and M. Mellado. 2014a. Effect of increasing levels of seven tree species extracts added to a high concentrate diet on in vitro rumen gas output. Anim. Sci. J. 85:853-860.

Salem, A. Z. M., A. E. Kholif, M. Olivares, M. M. Y. Elghandour, M. Mellado, and J. Arece, 2014b. Influence of S. babylonica extract on feed intake, growth performance and diet in vitro gas production profile in young lambs. Trop. Anim. Health Prod. 46:213-219. doi:10.1007/s11250013-0478-0.

Sariözkan, S., Y. Konca, B. K. Güçlü, E. Aktug, M. Kaliber, S. Özkan, and S.T. Ay, 2016. The Effect of Dietary Supplementation of Lemon Grass (Cymbopogon Citratus) on Performance, Carcass 
Quality, and Marketing of Quail (Coturnix Coturnix Japonica). Vet. Med. 98-103.

Shahidi, F., 2006. Functional Foods: Their Role in Health Promotion and Disease Prevention. J. Food Sci. 69:R146-R149. doi:10.1111/j.13652621.2004.tb10727.x.

Van Soest, P. J., J. B. Robertson, and B. A. Lewis, 2010. Methods for Dietary Fiber, Neutral Detergent Fiber, and Nonstarch Polysaccharides in Relation to Animal Nutrition. J. Dairy Sci. doi:10.3168/jds.s0022-0302(91)78551-2.

Van Soest, P., 1994. Nutritional ecology of the ruminant. Cornell Univ. Press. Ithaca London.
Tiwari, M. R., P. K. Jha, B. Sah, G. Kunwar, and A. K. Jha, 2018. Performance of lemongrass (Cymbopogon citrates) oil as growth promoter in broiler. Bangladesh J. Anim. Sci. 47:85-91.

Wanapat, M., A. Cherdthong, P. Pakdee, and S. Wanapat, 2008. Manipulation of rumen ecology by dietary lemongrass (Cymbopogon citratus Stapf.) powder supplementation. J. Anim. Sci. 86:3497-3503.

Warner, A. C. L., 1964. Production of volatile fatty acids in the rumen: methods of measurement. In: Nutrition Abstracts and Reviews. Vol. 34. p. 339352.

تأثير إضافة حشيشة الليمون والكركديه في عليقة النعاج الصعيدى على: (أ) إنتاج اللبن وتخمرات الكرش وعلى أداء الحملان

محمود عبد اللطيف محمد عبل الله'، ، محمد وائل حسن دغش' ، اسماء حسنى محمد منيب” ، محمد جمال محمد بخيت' ا ـ قسم الأتاج الحيوانس، كلية الزراعة، جامعة اسبيوط، ب ـ قسم علوم الألبان، كلبة الزراعة، جامعة اسيوط

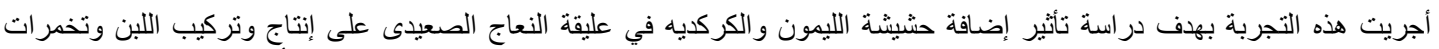

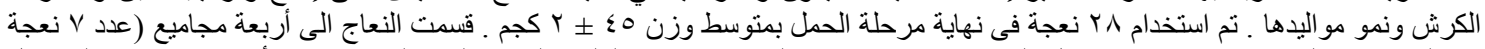

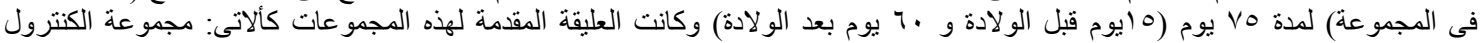

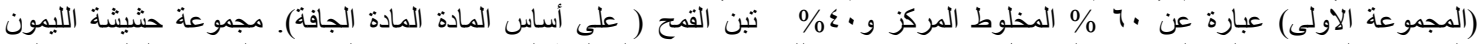

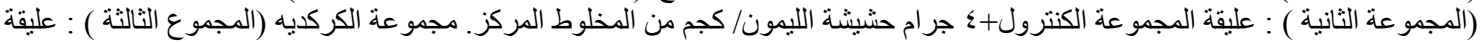

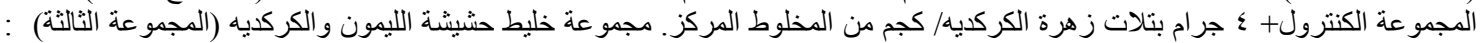

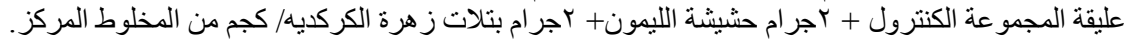

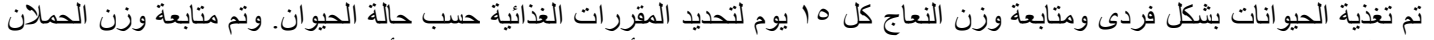

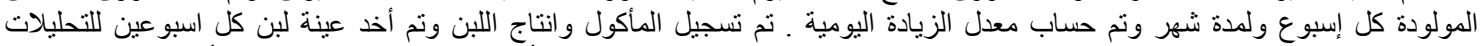

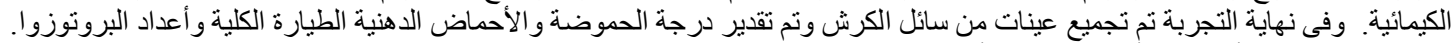

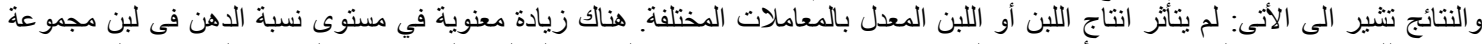

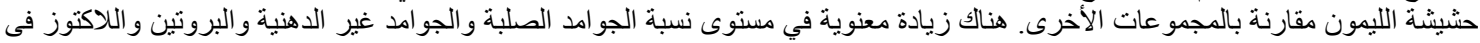

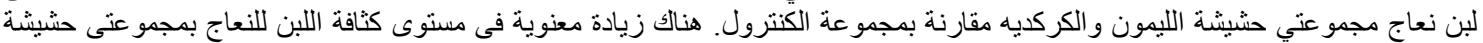

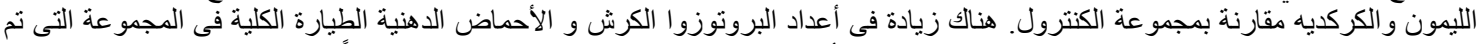

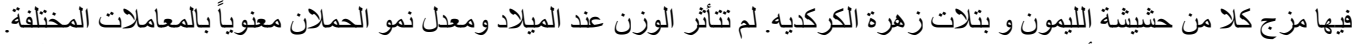

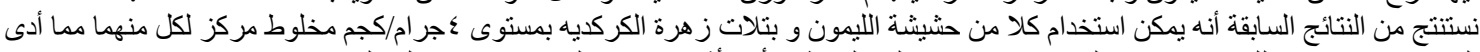
الى تحسين مكونات اللبن و تخمر ات الكرش في الاغنام ولكن لم يظهر أى نأثير معنوى هرة على معدلات نمو المو اليد. 